Zeszyty Naukowe Szkoły Głównej Gospodarstwa Wiejskiego

Ekonomika i Organizacja Gospodarki Żywnościowej nr 116, 2016: 57-66

Jan Hybel

Wyższa Szkoła Informatyki i Ekonomii TWP w Olsztynie

\title{
Tendencje i uwarunkowania migracji zagranicznych ludności w Polsce
}

\section{Wstęp}

Nieodłącznym elementem globalizacji i integracji są procesy migracji ludności. Migracje w Polsce rozwinęły się szczególnie po 1989 roku i po przystąpieniu Polski do UE. Problemy migracji są przedmiotem badań wielu dyscyplin, zarówno z perspektywy ekonomicznej, jak i demograficznej, politycznej oraz społecznej. Migracja oznacza zmianę miejsca pobytu mieszkańców danego kraju i może przybierać formę emigracji i imigracji. W ujęciu demograficznym migracja oznacza zmianę stałego miejsca zamieszkania i miejsca czasowego pobytu [Szczygielska 2013]. Według OECD migracja stała występuje, gdy osoba otrzymuje prawo stałego pobytu lub zezwolenie na pobyt stały [Murdoch 2011]. W zaleceniach ONZ migracje krótkookresowe dotyczą wyjazdów trwających od 3 do 12 miesięcy. W bazie Eurostat podawane są informacje o migracjach długookresowych (co najmniej 12 miesięcy).

Migracje są spowodowane głównie przyczynami ekonomicznymi, ale także politycznymi, rodzinnymi, religijnymi, zdrowotnymi oraz rozwojem turystyki. Wśród wielu teorii współczesnych objaśniających zjawisko migracji dominują dwa stanowiska: pierwsze, że o migracji decyduje zróżnicowanie płac i dochodów, a drugie akcentuje znaczenie sytuacji na rynku pracy, w tym wysoką stopę bezrobocia w kraju wysyłającym. W okresie transformacji systemowej migracje z przyczyn politycznych zupełnie straciły na znaczeniu. Swoboda przepływu osób w UE sprawia, że o emigracji w około $80 \%$ decyduje motyw zarobkowy [Kaczmarczyk 2006]. Ponadto w miejsce trwałej migracji zaczęły dominować wyjazdy osób na pobyt krótkookresowy. To utrudnia pełną analizę zjawiska migracji, bowiem nie jest łatwo ocenić, czy te wyjazdy mają charakter stały, czy tymczasowy. 
Celem opracowania jest przedstawienie zmian wielkości emigracji z Polski i imigracji do Polski oraz identyfikacja uwarunkowań ekonomicznych decydujących o wyborze kraju docelowego. Podstawę analizy stanowią materiały wtórne, literatura przedmiotu oraz dane GUS i Eurostat. Procesy migracyjne wymagają ciagłego gromadzenia informacji i opracowywania analiz niezbędnych do postawienia diagnozy zjawiska i wypracowania skutecznej polityki migracyjnej. Pogłębione badania pozwalają określić nie tylko skalę i kierunki migracji, ale także jej skutki gospodarcze, demograficzne i społeczne.

\section{Tendencje zmian i główne cechy oraz kierunki emigracji z Polski}

Z emigracją wiążą się zarówno korzyści, jak i zagrożenia, a także koszty, które można analizować z punktu widzenia osób emigrujących, firm i całej gospodarki. Do potencjalnych korzyści dla emigrantów można zaliczyć zatrudnienie i wyższe płace, zdobycie nowych kwalifikacji, poznanie nowej kultury i języka, a dla gospodarki kraju wysyłającego: zmniejszenie bezrobocia, wiedzą i umiejętności powracających, transfery pieniężne z zagranicy oraz korzyści firm transportowych. Do potencjalnych zagrożeń należą: utrata młodych ludzi, osób o wysokich kwalifikacjach, wystapienie braku specjalistów w niektórych dziedzinach, pogorszenie relacji między liczbą osób w produkcyjnym i poprodukcyjnym wieku, różne zagrożenia dla życia rodzinnego, wydatki na podróże i ryzyko związane z emigracją. Obecnie trudno jednoznacznie stwierdzić, czy emigracje są dla państwa korzystne, czy też powodują straty, głównie ze względu na zmieniającą się sytuację gospodarczą i zawężoną reprodukcję demograficzną zasobów pracy w Polsce i w wielu innych krajach. Część ekonomistów uważa, że zyski z migracji trafiają głównie do krajów przyjmujących, a nie wysyłających [Orłowski 2013]. Według GUS w 2014 roku poza krajem przebywało czasowo 2320 tys. Polaków (tab. 1).

W latach 2005-2014 liczba osób emigrujących czasowo z Polski zwiększyła się o 870 tys. osób, osiągając w 2014 roku 2320 tys. osób. Największa fala emigrantów była w latach 2005-2007. W następnych latach z powodu kryzysu gospodarczego zanotowano spadek liczby emigrantów, a od 2013 roku ponowny jej wzrost. Do zwiększenia emigracji (o 37,5\%) przyczyniło się głównie wprowadzenie zasady swobodnego przemieszczania się ludności w ramach UE i otwarcie granic. Kierunki emigracji z Polski były początkowo zdeterminowane tempem znoszenia ograniczeń w dostępie do rynku pracy w poszczególnych krajach UE. Głównymi kierunkami emigracji pozostają kraje UE, które przyjęły 82\% emigrantów. Najwięcej osób z Polski przybyło do: Wielkiej Brytanii, Niemiec i Irlandii, łącznie stanowi to $60,9 \%$ całej emigracji. 
Tabela 1

Liczba emigrantów z Polski przebywających czasowo za granicą w latach 2005 i 2012-2014 [tys. osób]

\begin{tabular}{|l|c|c|c|c|}
\hline Wyszczególnienie & 2005 & 2012 & 2013 & 2014 \\
\hline Ogółem & 1450 & 2130 & 2196 & 2320 \\
Europa & 1200 & 1816 & 1891 & 2013 \\
UE & 1170 & 1170 & 1789 & 1901 \\
w tym: & & & & \\
Austria & 25 & 28 & 31 & 34 \\
Belgia & 31 & 48 & 49 & 49 \\
Dania & 19 & 23 & 25 & 28 \\
Francja & 44 & 63 & 63 & 63 \\
Grecja & 17 & 14 & 12 & 9 \\
Holandia & 43 & 8 & 103 & 109 \\
Hiszpania & 37 & 37 & 34 & 32 \\
Irlandia & 76 & 118 & 115 & 113 \\
Niemcy & 430 & 500 & 560 & 614 \\
Szwecja & 17 & 38 & 40 & 43 \\
Wielka Brytania & 340 & 637 & 642 & 685 \\
Włochy & 70 & 97 & 96 & 96 \\
spoza UE & 30 & 96 & 102 & 112 \\
Norwegia & 24 & 65 & 71 & 79 \\
\hline
\end{tabular}

Źródło: GUS [2015c].

W latach 2012-2015 znacząco wzrosła liczba osób emigrujących do Niemiec (o 114 tys. osób), głównie ze względu na bliskie sąsiedztwo, niską stopę bezrobocia i duże zapotrzebowanie na pracę oraz wysokie płace. Należy również zauważyć znaczący wzrost liczby emigrantów z Polski do Wielkiej Brytanii, Norwegii, Włoch, Holandii i Austrii, natomiast spadek do Grecji i Hiszpanii, a od 2012 roku do Irlandii.

$\mathrm{Z}$ danych zestawienia w tabeli 2 wynika, że najwięcej osób emigruje z województw: opolskiego, podlaskiego i podkarpackiego.

Według badań GUS główną przyczyną emigracji, zarówno mężczyzn, jak i kobiet, była możliwość znalezienia zatrudnienia dającego wyższy zarobek niż w Polsce. Na tę przyczynę w 2014 roku wskazało 78,7\% mężczyzn i 62,2\% kobiet. Kolejnymi przyczynami były: łączenie rodzin i edukacja - 16,5\% odpowiedzi mężczyzn i 30,8\% odpowiedzi kobiet. Z wyżej wymienionych badań wynika, że z Polski emigrują głównie osoby z wykształceniem średnim (40,5\%) i wyższym $(22,8 \%)$ - tabela 3 . 
Tabela 2

Udział emigrantów w liczbie ludności według województw w Polsce w 2014 roku [\%]

\begin{tabular}{|l|c|l|c|}
\hline \multicolumn{1}{|c|}{ Województwo } & Udział & \multicolumn{1}{c|}{ Województwo } & Udział \\
\hline Dolnośląskie & 6,2 & Podkarpackie & 8,4 \\
\hline Kujawsko-pomorskie & 5,1 & Podlaskie & 9,1 \\
\hline Lubelskie & 5,2 & Pomorskie & 5,9 \\
\hline Lubuskie & 6,0 & Śląskie & 5,0 \\
\hline Łódzkie & 2,9 & Świętokrzyskie & 5,0 \\
\hline Małopolskie & 5,6 & Warmińsko-mazurskie & 7,5 \\
\hline Mazowieckie & 2,8 & Wielkopolskie & 3,1 \\
\hline Opolskie & 10,6 & Zachodniopomorskie & 6.3 \\
\hline
\end{tabular}

Źródło: Jak w tabeli 1.

Tabela 3

Przyczyny emigracji Polaków w 2014 roku [\%]

\begin{tabular}{|l|c|c|}
\hline Rodzaj przyczyny & Mężczyźni & Kobiety \\
\hline Praca & 78,7 & 62,2 \\
Edukacja & 3,9 & 8,4 \\
Leczenie & 0,2 & 0,3 \\
Sprawy rodzinne & 12,6 & 22,4 \\
Pozostałe & 4,6 & 6,7 \\
\hline
\end{tabular}

Źródło: GUS [2015a].

Emigracja osób o wysokich kwalifikacjach powoduje ubytek kapitału ludzkiego i jest szczególnie niekorzystna dla kraju w przypadku wyjazdów na pobyt stały, a w małym stopniu w czasowej i cyrkulacyjnej migracji. Poziom i dynamika migracji zagranicznej z Polski są stosunkowo niewielkie (tab. 4).

Tabela 4

Emigranci wymeldowani z pobytu stałego w Polsce w latach 2005 i 2014

\begin{tabular}{|c|c|c|c|}
\hline \multirow{2}{*}{ Wyszczególnienie } & 2005 & 2014 & \multirow{2}{*}{$\begin{array}{l}\text { 2014/2005 } \\
\text { przyrost [\%] }\end{array}$} \\
\hline & \multicolumn{2}{|c|}{ liczba osób } & \\
\hline Ogółem & 22242 & 28080 & 26,2 \\
\hline $\begin{array}{l}\text { w tym do Europy: } \\
\text { w tym: }\end{array}$ & 18416 & 25031 & 35,9 \\
\hline Wielka Brytania & 3072 & 7392 & 140,6 \\
\hline Irlandia & 405 & 1196 & 195,3 \\
\hline Kanada & 808 & 673 & $-32,7$ \\
\hline USA & 2633 & 1877 & $-28,7$ \\
\hline
\end{tabular}

Źródło: GUS [2015b]. 
Z przedstawionych danych w tabeli 4 wynika, że liczba emigrantów na pobyt stały w badanym okresie wzrosła o $25,2 \%$, w tym najbardziej do Irlandii (o 195\%) i Wielkiej Brytanii (o 141\%), natomiast znacznie spadła do Kanady i USA, odpowiednio o 33 i 29\%. Należy zaznaczyć, że statystyka GUS odnotowuje fakt wymeldowania z pobytu stałego w Polsce, a nie rzeczywistego opuszczenia kraju. Ponadto wzrost liczby emigrantów może wynikać z faktu, że po wejściu Polski do UE ujawniły się osoby pracujące zagranicą „na czarno”.

\section{Tendencje zmian wielkości imigracji cudzoziemców do Polski}

Wraz z wejściem Polski do UE i przyjęciem do strefy Schengen istotnie wzrosła atrakcyjność Polski dla cudzoziemców z byłego ZSSR jako kraju docelowego, a także tranzytowego do Europy Zachodniej.

Statystykę imigracji do Polski prowadzi wiele instytucji, m.in.: GUS, Eurostat, Ministerstwo Rodziny, Pracy i Spraw Socjalnych, Urząd ds. Cudzoziemców. Najczęściej publikowane dane statystyczne są zaniżone z uwagi na istnienie imigracji cyrkulacyjnej i imigracji nielegalnej. Według zarejestrowanych oświadczeń liczba imigrantów tymczasowych zwiększyła się z 250,8 tys. w 2011 roku do 387,4 tys. osób w 2014 roku.

$\mathrm{Z}$ uwagi na brak pełnych danych o rzeczywistej imigracji w opracowaniu zostały wykorzystane informację o liczbie imigrantów na podstawie zezwoleń na pracę (tab. 5).

Największe zainteresowanie polskim rynkiem pracy jest ze strony obywateli Ukrainy, Wietnamu, Chin i Białorusi. Liczba wydanych zezwoleń na pracę najbardziej wzrosła dla osób z Uzbekistanu (o 71\%) i Ukrainy (o 41\%), natomiast spadła dla osób z Chin, Wietnamu i Turcji.

\section{Tabela 5}

Liczba zezwoleń na pracę w Polsce wydanych w latach 2011-2014

\begin{tabular}{|l|c|c|c|c|}
\hline Kraj & 2011 & 2012 & 2013 & 2014 \\
\hline Ukraina & 18669 & 20295 & 20416 & 26315 \\
Chiny & 5854 & 3247 & 2089 & 2133 \\
Wietnam & 2504 & 2302 & 2230 & 2369 \\
Białoruś & 1725 & 1949 & 2004 & 1834 \\
Uzbekistan & 619 & 958 & 948 & 1060 \\
Mołdawia & 1017 & 616 & 699 & 1027 \\
Indie & 1055 & 1090 & 1300 & 1025 \\
Turcja & 1187 & 1063 & 967 & 689 \\
Rosja & 549 & 719 & 822 & 654 \\
\hline
\end{tabular}

Źródło: Ministerstwo Pracy i Polityki Społecznej. 
Wśród zezwoleń na pracę dla osób z Ukrainy dominowali robotnicy wykwalifikowani i pracownicy do prac prostych w takich dziedzinach, jak rolnictwo, budownictwo i handel (w sumie 80,7\%) oraz kadra kierownicza $(14,8 \%$ ), a w małym stopniu informatycy, lekarze, nauczyciele i artyści. To oznacza, że imigracja ze Wschodu spełnia obecnie głównie rolę komplementarną na polskim rynku pracy. Imigracja do Polski ma charakter czasowy, a w niewielkim stopniu na pobyt stały (tab. 6).

W analizowanym okresie liczba imigrantów stałych zwiększyła się o 31,7\%, głównie z Wielkiej Brytanii i Irlandii. Spadek liczby imigrantów z Europy Wschodniej wynika głównie z tego, że znaczna ich część traktuje Polskę jako kraj tranzytowy. Zwiększający napływ imigrantów jest wynikiem wprowadzenia Karty Polaka, małego ruchu granicznego oraz ułatwień dotyczących obywateli z Europy Środkowo-Wschodniej.

Uwzględniając jednocześnie liczbę emigrantów i imigrantów, możemy ustalić wielkość salda migracji (tab. 7).

\section{Tabela 6}

Liczba imigrantów zamieszkałych na pobyt stały w Polsce w latach 2005 i 2014

\begin{tabular}{|c|c|c|c|}
\hline \multirow{2}{*}{ Wyszczególnienie } & 2005 & 2014 & \multirow{2}{*}{$\begin{array}{c}\text { 2014/2005 } \\
\text { przyrost [\%] }\end{array}$} \\
\hline & \multicolumn{2}{|c|}{ liczba osób } & \\
\hline Ogółem & 9364 & 12330 & 31,7 \\
\hline $\begin{array}{l}\text { Europa } \\
\text { w tym: }\end{array}$ & 6906 & 10049 & 45,5 \\
\hline Wielka Brytania & 468 & 2944 & 129,0 \\
\hline Irlandia & 320 & 586 & 83,1 \\
\hline Kanada & 303 & 235 & $-22,5$ \\
\hline USA & 1289 & 1059 & $-17,8$ \\
\hline Ukraina & 1196 & 749 & $-37,4$ \\
\hline
\end{tabular}

Źródło: Jak w tabeli 5.

\section{Tabela 7}

Saldo emigracji i imigracji na pobyt stały w Polsce w latach 2005 i 2014

\begin{tabular}{|l|c|c|c|}
\hline Wyszczególnienie & 2005 & 2014 & $2014 / 2005$ \\
\hline Ogółem osób & -12878 & -15750 & 122,3 \\
Do i z: & & & \\
Europy & -11510 & -14982 & 129,4 \\
Wielkiej Brytanii & -2604 & -4448 & 170,8 \\
Irlandii & -373 & -610 & 163,5 \\
Kanady & -505 & -458 & 90,7 \\
USA & -1344 & -818 & 60,9 \\
Ukrainy & -1181 & -718 & 60,8 \\
\hline
\end{tabular}

Źródło: Jak w tabeli 5. 
Polska jest obecnie i w najbliższym okresie pozostanie krajem emigrantów, bowiem ich liczba przewyższa o 22,3\% liczbę imigrantów. Szczególnie wysokie ujemne saldo migracji prz dotyczy przepływów między Polską a Wielką Brytanią i Irlandią. Tego typu sytuacja utrzyma się przez pewien okres, ale niezbyt długo, bowiem Polska zacznie odczuwać niedobór siły roboczej i skutki starzenia się społeczeństwa. W związku z powyższym będzie konieczne w najbliższym okresie znaczne zwiększenie liczby imigrantów nie tylko z Europy Wschodniej, ale także z Bliskiego Wschodu i Afryki.

\section{Główne uwarunkowania zjawiska migracji ludności}

W opracowaniu zostaną uwzględnione główne czynniki: poziom PKB na mieszkańca, wskaźnik zatrudnienia i stopa bezrobocia oraz średnie zarobki brutto w przedsiębiorstwach zatrudniających powyżej 10 pracowników.

Dane zestawione w tabeli 8 wskazują, że nadal utrzymuje się duży dystans w poziomie rozwoju między krajami starej UE i pozostałymi państwami członkowskimi. Im to zróżnicowanie jest większe, tym większy jest przepływ siły roboczej.

Drugim czynnikiem wpływającym na rozwój migracji jest sytuacja na rynku pracy w kraju emigracji i kraju docelowym. Aby ją ocenić, należy przeprowadzić

\section{Tabela 8}

Poziom PKB na mieszkańca według siły nabywczej w wybranych krajach UE w latach 2004 , 2010 i 2014 (średnia UE = 100)

\begin{tabular}{|c|c|c|c|}
\hline Kraje & 2004 & 2010 & 2014 \\
\hline \multicolumn{4}{|c|}{ Najwyższy poziom } \\
\hline Luksemburg & 253 & 262 & 264 \\
\hline Austria & 128 & 126 & 129 \\
\hline Szwecja & 127 & 123 & 127 \\
\hline Holandia & 129 & 130 & 127 \\
\hline Irlandia & 143 & 128 & 126 \\
\hline Dania & 126 & 128 & 125 \\
\hline Niemcy & 116 & 120 & 124 \\
\hline Wielka Brytania & 125 & 108 & 106 \\
\hline \multicolumn{4}{|c|}{ Najniższy poziom } \\
\hline Bułgaria & 35 & 44 & 47 \\
\hline Rumunia & 35 & 51 & 54 \\
\hline Węgry & 63 & 66 & 67 \\
\hline Łotwa & 47 & 55 & 66 \\
\hline Polska & 51 & 63 & 68 \\
\hline
\end{tabular}

Źródło: Obliczenia własne na podstawie Eurostat [2015]. 
Tabela 9

Wskaźnik zatrudnienia i stopa bezrobocia w wybranych krajach UE w latach 2004 i 2014 [\%]

\begin{tabular}{|l|c|c|c|c|}
\hline \multirow{2}{*}{ Wyszczególnienie } & \multicolumn{2}{|c|}{ Wskaźnik zatrudnienia } & \multicolumn{2}{c|}{ Stopa bezrobocia } \\
\cline { 2 - 5 } & 2004 & 2014 & 2004 & 2014 \\
\hline UE-28 & 62,9 & 64,3 & 9,2 & 10,9 \\
Polska & 51,7 & 60,1 & 19,1 & 9,8 \\
Niemcy & 65,0 & 73,4 & 10,5 & 5,4 \\
Wielka Brytania & 71,7 & 70,7 & 4,7 & 7,5 \\
Dania & 75,7 & 72,5 & 5,5 & 7,2 \\
Holandia & 73,1 & 74,3 & 5,1 & 6,8 \\
Hiszpania & 61,3 & 54,9 & 11,0 & 26,4 \\
\hline
\end{tabular}

Źródło: Jak w tabeli 8.

analizę wskaźników zatrudnienia i bezrobocia w krajach przyjmujących i wysyłających. Kraje przyjmujące imigrantów charakteryzują w porównaniu z Polską znacznie wyższe wskaźniki zatrudnienia (tab. 9).

Przeciętna stopa bezrobocia w UE nieznacznie wzrosła, ale w krajach docelowej migracji była znacznie mniejsza w porównaniu do Polski i Hiszpanii. Dane przedstawione w tabeli 9 wskazują, że migranci napływają do krajów o wysokim wskaźniku zatrudnienia i i niskiej stopie bezrobocia.

Kolejnym równie ważnym czynnikiem emigracji jest dążenie do poprawy sytuacji materialnej i stopy życiowej. Jednym z jej wyznaczników jest wyższy poziom zarobków i płacy minimalnej oraz różnego typu świadczenia socjalne (tab. 10).

Od 2004 roku sytuacja dochodowa w nowych krajach UE uległa znacznej poprawie, ale nie na tyle, aby dorównać krajom bogatym. To zróżnicowanie w poziomie dochodów będzie istnieć pewnie przez wiele lat i pozostanie nadal jako główny motyw stymulujący rozwój zjawiska migracji. Do podobnych

\section{Tabela 10}

Średnioroczne zarobki brutto i płace minimalne w wybranych krajach UE w latach 2004 i 2012 [EUR]

\begin{tabular}{|l|c|c|c|c|}
\hline \multirow{2}{*}{ Kraje } & \multicolumn{2}{|c|}{ Zarobki brutto } & \multicolumn{2}{c|}{ Płace minimalne } \\
\cline { 2 - 5 } & 2004 & 2012 & 2004 & 2013 \\
\hline Dania & 46122 & 56820 & - & - \\
Luksemburg & 40575 & 49720 & 1403 & 1874 \\
Wielka Brytania & 41285 & 38831 & 1054 & 1250 \\
Holandia & 37900 & 45916 & 1265 & 1469 \\
Niemcy & 38100 & 43125 & - & - \\
Polska & 6230 & 11396 & 175 & 393 \\
Słowacja & 5706 & 10947 & 148 & 338 \\
Bułgaria & 1784 & 4670 & 61 & 159 \\
Rumunia & 2414 & 5982 & 68 & 158 \\
\hline
\end{tabular}

Źródło: Eurostat [2014], dostęp on-line http:/Europa.en/eurostat/ population_statistic. 
wniosków prowadzą również analizy przeprowadzane przez Ośrodek Badań nad Migracjami, wskazujące na ekonomiczny motyw współczesnej migracji [Małachowski 2010].

\section{Podsumowanie i wnioski}

Celem opracowania jest identyfikacja zmian skali zjawiska emigracji i imigracji oraz ich głównych uwarunkowań w okresie po akcesji Polski do UE. Na podstawie przeprowadzonej analizy można sformułować następujące wnioski:

1. Emigracja z Polski ma zasadniczo charakter zarobkowy, a jej główną przyczyną jest niekorzystna sytuacja na wewnętrznym rynku pracy, w tym wysokie bezrobocie. Rozmiary emigracji z Polski zarówno na pobyt stały, jak i czasowy znacznie wzrosły po wejściu Polski do UE. W ostatnich latach znacząco zmalała emigracja do Stanów Zjednoczonych.

2. Polska jest i będzie w najbliższym okresie krajem emigrantów, bowiem skala imigracji do Polski mimo wzrostu liczby emigrantów jest niewielka, a w stosunku do liczby ludności jest jedną z najmniejszych w Europie. Czynnikiem przyciągającym imigrantów do Polski jest głównie wyższy poziom zarobków niż w ich ojczystym kraju i możliwość tranzytu do Europy Zachodniej.

3. Oddziaływanie migracji na gospodarkę jest wielokierunkowe, zarówno korzystne, jak i niekorzystne, powoduje zmiany sytuacji na rynku pracy i w stosunkach demograficznych.

4. Wielkość migracji jest niedoszacowana, bowiem emigranci długookresowi się nie wymeldowują, a emigranci czasowi nie zgłaszają swoich wyjazdów oraz część imigrantów przebywa w Polsce nielegalnie.

5. Konieczne są zmiany w dotychczasowej polityce migracyjnej, polegające na wypracowaniu elastycznych, bardziej skutecznych jej instrumentów odpowiednich do zmieniających się obecnie warunków politycznych i ekonomicznych.

\section{Literatura}

GUS, 2015a: Badania aktywności ekonomicznej ludności, Warszawa.

GUS, 2015b: Główne kierunki emigracji i imigracji na pobyt stały, Warszawa.

GUS, 2015c: Informacja o rozmiarach i kierunkach czasowej emigracji z Polski, Warszawa.

KACZMARCZYK P., 2006: Wspótczesne migracje zagraniczne Polaków - skala, struktura oraz potencjalne skutki dla rynku pracy, Ośrodek Badań nad Migracjami, Wydawnictwo UW, Warszawa. 
KACZMARCZYK P., 2005: Migracje zarobkowe Polaków w dobie przemian, Wydawnictwo UW, Warszawa.

MATKOWSKA M., 2015: Procesy migracyjne w poakcesyjnej Polsce, Prace i Studia 40, 1.

MAŁACHOWSKI W., 2010: Migracje we wspótczesnym świecie. Implikacje dla Polski, Oficyna Wydawnicza SGH, Warszawa.

MURDOCH A. 2011: Emigracja lekarzy z Polski, Oficyna Wydawnicza SGH, Warszawa.

ORŁOWSKI R., 2013: Uwarunkowania i skutki rozwoju migracji ekonomicznych w Unii Europejskiej w świetle wybranych teorii międzynarodowych, Wydawnictwo UG, Gdańsk.

SZCZYGIELSKA I., 2013: Migracje zarobkowe kobiet i ich wplyw na funkcjonowanie rodziny, Wydawnictwo UW, Warszawa.

\title{
Tendencies and causes of foreign migration in Poland
}

\begin{abstract}
The paper presents scale, dynamics and directions as well as main causes and effects of foreign migrations from Poland. It begins with the analysis of the scale of the emigration, followed by the analysis of the immigration of foreigners. The research was carried out in the years 2005-2014. While analysing the causes of migrations, the differences in the level of economic development and incomes as well as general situation on the labour markets in selected EU countries were studied. It is concluded that immigration to Poland is caused mainly by income level, while emigration results mostly from the level of unemployment in the country of origin.
\end{abstract}

Key words: labour market, migration, emigration, immigration 